\title{
REPRODUCTIVE RISK OF PARACENTRIC INVERSION CARRIERS: REPORT OF TWO UNRELATED CASES WITH PARACENTRIC INVERSION OF THE LONG ARM OF CHROMOSOME 3
}

\author{
Ryozo Kasai, ${ }^{1}$ Kouji Narahara, ${ }^{2}$ Kiyoshi KikKawa, ${ }^{2}$ \\ Yukio Takahashi, ${ }^{2}$ Y oshiharu WaKita, ${ }^{2}$ Shunsuke Kimura, ${ }^{2}$ \\ Naoki KaTAOKA, ${ }^{3}$ and Hiroshi KImOTO ${ }^{2}$ \\ 'Asahigawa Jidoin Children's Hospital, Gionchisaki, Okayama 703, Japan \\ ${ }^{2}$ Department of Pediatrics, Okayama University School of Medicine, \\ Shikata-cho, Okayama 700, Japan \\ ${ }^{3}$ Department of Pediatrics, Kawasaki Medical School, \\ Matsushima, Kurashiki 701-01, Japan
}

\begin{abstract}
Summary Two unrelated cases with a paracentric inversion involving the long arm of a chromosome 3 were described. One case was a 29year-old female with habitual spontaneous abortions. The karyotype was 46,XX,inv(3)(q25q27). The other case was a two year one month-old girl with growth and psychomotor retardation and multiple minor anomalies. She was found to have a recombinant chromosome 3 resulting from a paternal paracentric inversion. The karyotype of the patient was $46, \mathrm{XX}$, rec(3), dup(q26.3), inv(3)(q12q29)pat. The review of previously reported cases showed a considerable risk for live-born recombinants derived from parental paracentric inversions and the analysis of reproductive histories of inversion carriers suggested a possible contribution of this type of chromosome abnormalities to the cause of spontaneous abortions.
\end{abstract}

\section{INTRODUCTION}

A paracentric inversion has generally been considered to be an exceedingly rare structural abnormality in human chromosomes, because no description was made in the consecutive cytogenetic newborn studies (Hook and Hammerton, 1977). Improvement of resolution in chromosome banding analysis, however, has accelerated the discovery of cases with paracentric inversions. The reliable estimate of the incidence of paracentric inversion in human population has recently been provided by Van Dyke et al. (1983). According to their data, which were obtained from three series of advanced maternal-age prenatal cytogenetic studies, 4 out of

Received January 19, 1985 
8,158 individuals ( 1 in 2,040) were found to carry a paracentric inversion. A similar figure has been reported by Hook et al. (1984), who detected 6 cases with paracentric inversions in 24,951 fetuses ( 1 in 4,159). The overall incidence from these studies is 1 in $3,311(10 / 33,109)$. Thus, the occurrence of paracentric inversions in humans is by far more frequent than was previously suspected.

On the other hand, Fryns and Van den Berghe (1980) found 7 cases with paracentric inversions in 14,500 patients $(1$ in 2,071$)$ in whom chromosome analyses were carried out for diagnosis of abnormal phenotypes or genetic counseling. Surprisingly, the figure is similar to that of the prenatal studies, and the question of whether paracentric inversions are really related to abnormal phenotypes remains open.

In this paper, two unrelated cases with a paracentric inversion of the long arm of a chromosome 3 were presented. One case had multiple spontaneous abortions, while the other case with growth and psychomotor retardation and multiple minor anomalies was found to have a recombinant chromosome. Previously reported cases are reviewed with special respect to the reproductive risk of inversion carriers for liveborn recombinants and spontaneous abortions.

\section{CASE REPORT}

\section{Case 1}

The patient, a 29-year-old female of normal intelligence, and her husband were referred to us for chromosome analysis after three spontaneous abortions. There was no family history for miscarriages or congenital malformations. The patient had menarche at 13 years of age with subsequent regular menstruations. They were married when she was 24 years old. The first pregnancy resulted in mid-trimester abortion (at 5 month's gestation), and a fetus weighing $700 \mathrm{~g}$ was apparently normal. The second and third spontaneous abortions occurred at 2 months' and 5 months' gestation, respectively. She was $154 \mathrm{~cm}$ tall, weighing $50.5 \mathrm{~kg}$. No overt malformations were present. However, hysterosalpingography revealed a bicornuate uterus (Fig. 1).

\section{Case 2}

The patient, a 2 year one month-old girl, was born to a healthy 26-year-old mother and an unrelated 31-year-old father. The parents and her three siblings had normal phenotypes. There was no family history for miscarriages, congenital anomalies, or mental retardation. The pregnancy was complicated by anemia in the early trimester and hyperemesis throughout the pregnancy. The delivery occurred at term in the vertex position with no asphyxia. At the patient's birth, the body weight was $2,550 \mathrm{~g}$, and the length $45.0 \mathrm{~cm}$. At age of two years one month, she was admitted to Department of Pediatrics, Kawasaki Medical School Hospital for evaluation of growth and psychomotor retardation.

Physical examination of the patient at admission showed that the body weight 
was $6,950 \mathrm{~g}$ (less than third percentile), the height $73.6 \mathrm{~cm}$ (less than third percentile), and the head circumference $43.5 \mathrm{~cm}$ (less than third percentile). The child had peculiar craniofacial features (Fig. 2), including thin hair, frontal bossing, prominent nasal bridge, low-set and posteriorly rotated ears with prominent antihelices, small mouth, thin upper lip, and micrognathia with pointed chin. Anterior fontanel was still open $(1.5 \mathrm{~cm} \times 1.5 \mathrm{~cm})$. Examinations of chest and abdomen were normal. There were no heart murmurs. Toes were short, with a cutaneous syndactyly between the second and third toes. Simian creases were present on the bilateral palms. She spoke only a few words, and developmental quotient was 80 . Laboratory investigations including complete blood count, urinalysis, and blood chemistry gave normal results except for iron deficiency anemia. Bone age was appropriate for chronological age, and endocrinological studies were also normal. Intravenous

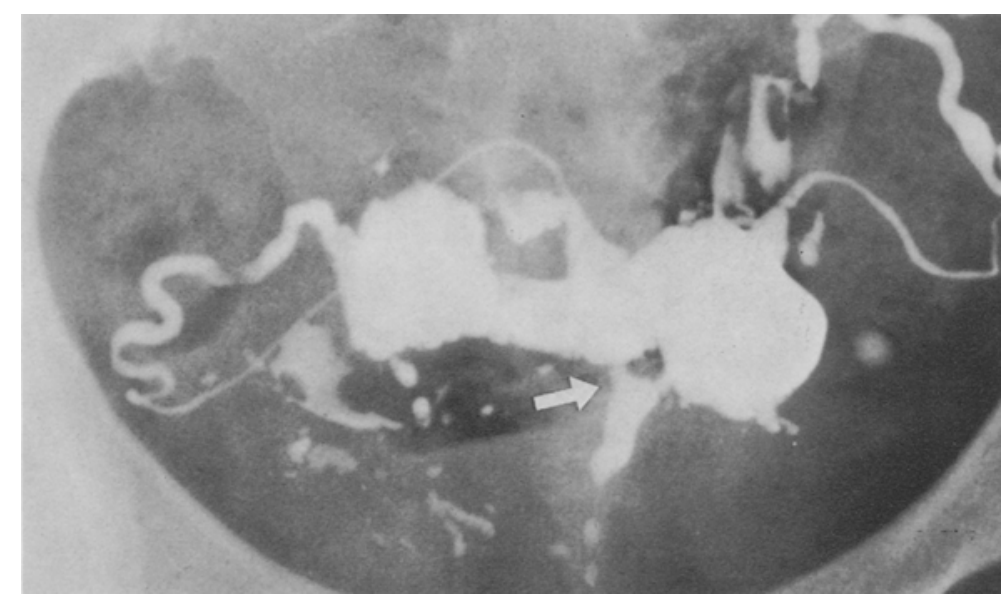

Fig. 1. Case 1. Hysterosalpingogram. An arrow indicates a bicornuate uterus.
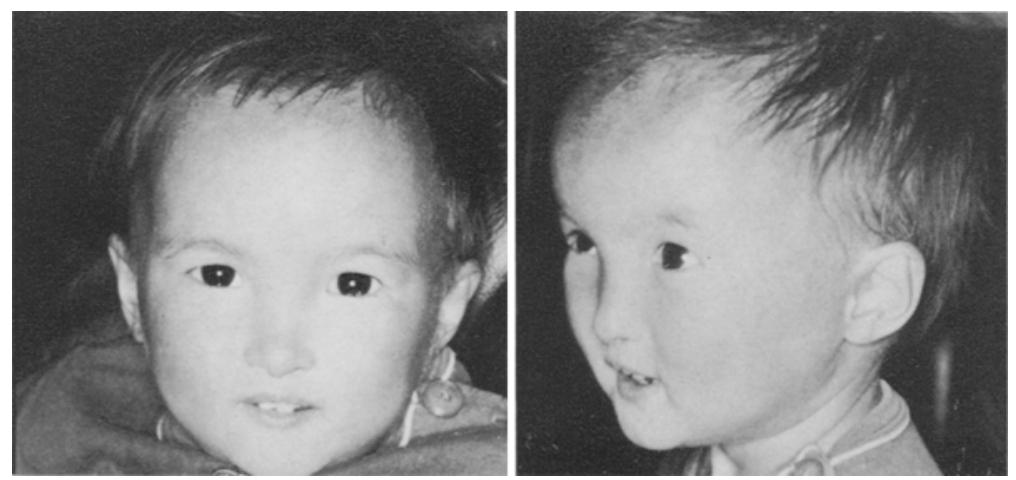

Fig. 2. Case 2. Frontal and lateral views. 
pyelography and computed tomography of the head showed no abnormalities.

Her subsequent growth and speech development was slow. At age of 4 years 5 months, she died suddenly from acute myocarditis. Autopsy was not granted.

\section{CYTOGENETIC FINDINGS}

Peripheral blood lymphocytes were cultured with the conventional method. Chromosome analyses were carried out by use of GTG banding techniques.

The karyotype of case 1 showed a paracentric inversion involving the distal portion of the long arm of a chromosome 3, with the breakpoints apparently at q25 and q27 (Fig. 3). The karyotype was designated as 46,XX,inv(3)(q25q27). Chromosome analysis of her family members was unavailable.

The karyotype of metaphase cells from case 2 revealed a paracentric inversion involving the nearly whole part of the long arm of a chromosome 3 . Chromosome analysis of the parents showed that the father was found to have an apparently same paracentric inversion as the case, with breakpoints at q12 and q29. Cytogenetic studies of prometaphase cells, however, demonstrated an additional small dark band on the inverted chromosome 3 of the child, which was not present on that of the father (Fig. 4). On the basis of the banding patterns, the additional band of the
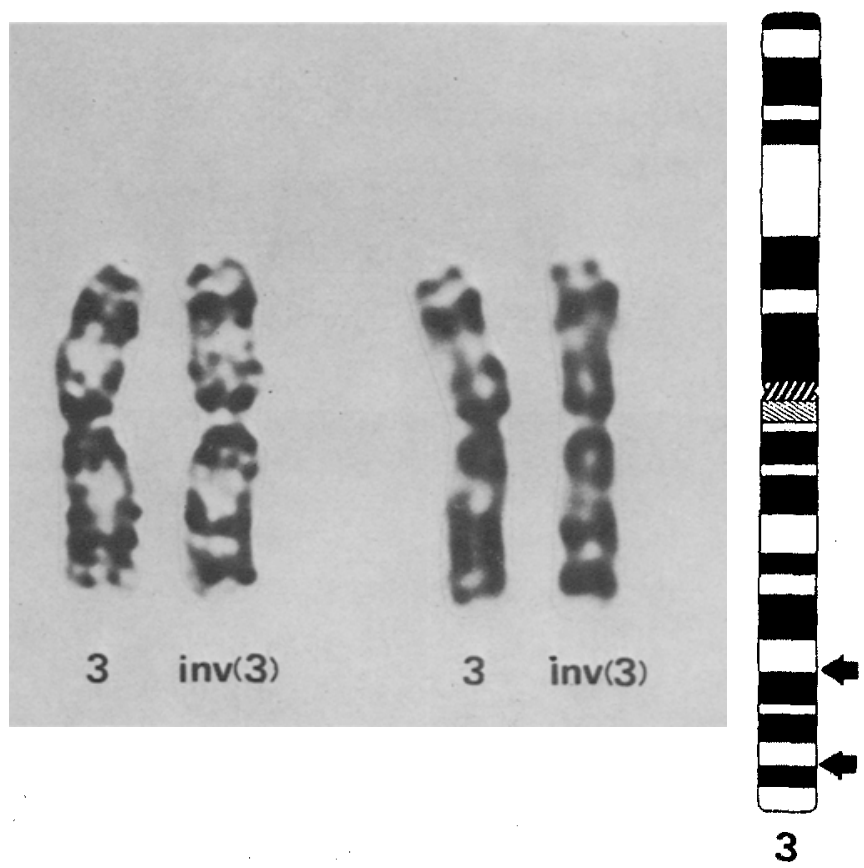

Fig. 3. Partial G-banded karyotypes of case 1. Arrows indicate breakpoints. 

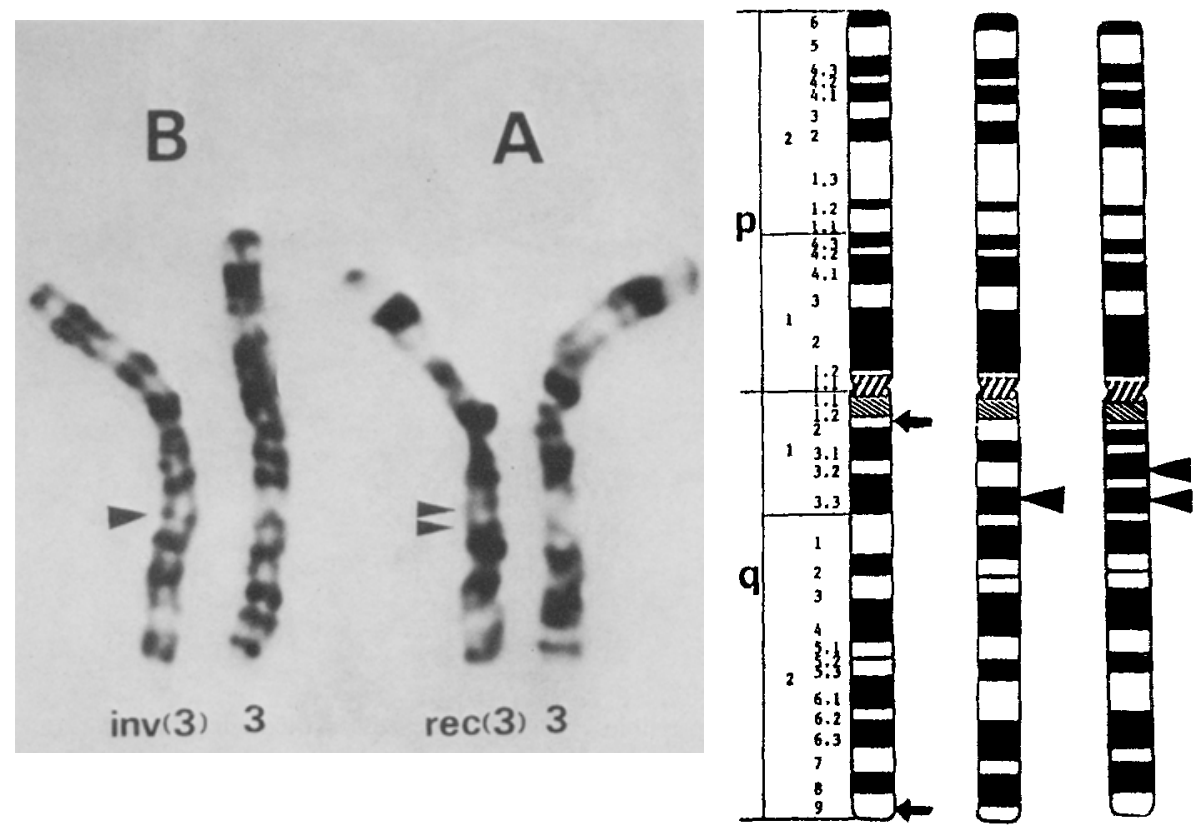

\section{3 inv(3) $\operatorname{rec}(3)$}

Fig. 4. Partial G-banded karyotypes of prometaphase cells from case 2 (A) and the father (B), corresponding to the level of 550 bands in a haploid set (ISCN, 1981). Arrows indicate breakpoints, and arrowheads a $3 q 26.3$ segment, which was duplicated on the inverted chromosome 3 (rec 3 ) in case 2 .

patient's chromosome 3 appeared to be $3 q 26.3$. The duplication was assumed to result from an unusual recombination between the inverted chromosome 3 and normal homologue in meiosis of the father (Fig. 5). The chromosome formula of case 2 was designated as $46, X X, \operatorname{rec}(3), \operatorname{dup}(q 26.3), \operatorname{inv}(3)(q 12 q 29)$ pat. The mother and three siblings had normal chromosomes.

\section{DISCUSSION}

Since the first description of a case with a paracentric inversion of the long arm of a chromosome 16 by Del Solar and Uchida (1974), 29 cases with paracentric inversions including ours have been published in the literature (Table 1). The inversions involved certain chromosomes more frequently: chromosome 3 in 8 instances (cases 3, 7, 11, 12, 19, 25, 28, and 29) and chromosome 7 in 6 (cases 2, $5,15,18,20$, and 24). It is interesting that the breakpoints on those chromosomes converge to the specific chromosome sites (3p13 and 3p25 in 4 cases, and $7 \mathrm{q} 11$ and $7 \mathrm{q} 22$ in 4 cases). Ascertainments of paracentric inversions among the reported cases 


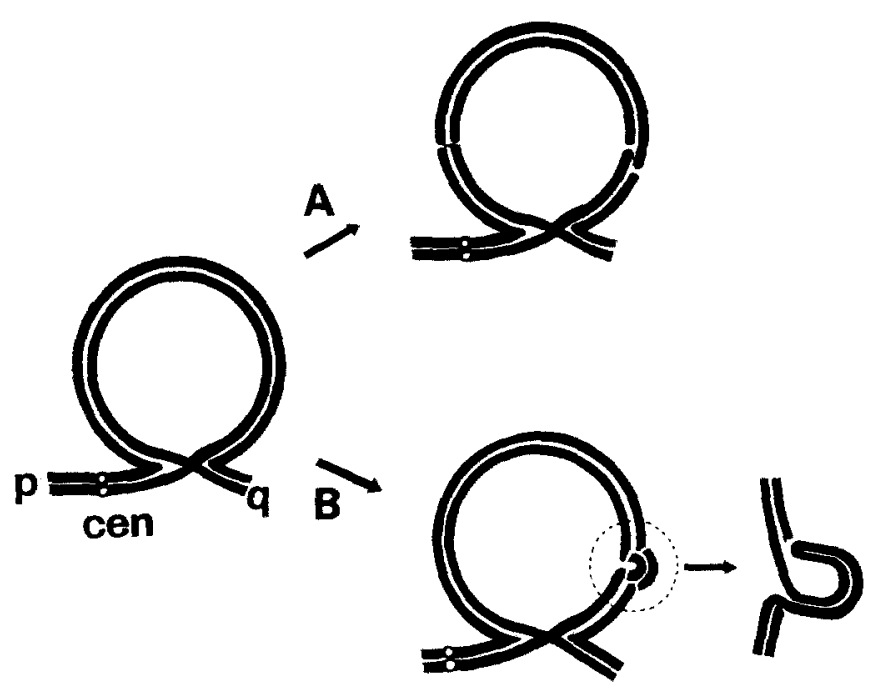

Fig. 5. Schematic representation of possible cytogenetic processes through which a tiny interstitial duplication in case 2 was produced in the meiotic inversion loop of the father. A: an even number of crossing-over with unequal one involving the duplicated segment, B: U-type exchange within the inversion loop.

were made through a progeny with a recombinant chromosome in 5 cases (cases 9 , $18,23,27$, and 29), some phenotypic abnormalities in 12 cases (cases $1,3,4,5,6,7$, $8,10,11,17,19$, and 22), multiple spontaneous abortions in 4 cases (cases 14, 24, 25 , and 28), or miscellaneous conditions in 8 cases (cases 2, 12, 13, 15, 16, 20, 21, and 26). The majority of the cases with inversions (23/29) are familial, and the remaining cases are de novo ( 2 cases) or undetermined ( 4 cases). Most of the index patients of the familial cases are associated with various congenital malformations or mental retardation, or both, although the same inversions are found in normal relatives. In six cases, an additional chromosome aberration is present (47, XXY in cases 4 and $17,45, X$ in case 5, and partial trisomy $10 \mathrm{q}$ in case 3 ), or another obvious cause for the phenotypic abnormality is evident (the mother's use of many antiepileptic drugs during the pregnancy in case 19, and the close parental consanguinity in case 22). The association may be coincidental also in the three familial cases (cases 1,6, and 7) as well as two de novo cases (cases 8 and 10) with phenotypic abnormalities. However, there is a possibility that altered phenotypes are caused by paracentric inversions through mechanisms analogous to those speculated in familial or de novo translocation cases with phenotypic abnormalities (Jacobs, 1974; Bühler, 1983).

Individuals carrying chromosome inversions are predisposed to have unbalanced gametes through 'aneusomic recombination.' An odd number of crossingover within a pericentric inversion loop produces duplication-deficiency gametes, 
while that within a paracentric inversion loop yields dicentric and acentric products which are unstable and probably nonviable. Nonetheless, 4 cases have been reported to have recombinant chromosomes derived from parental paracentric inversions: a dicentric recombinant (case 27), a disruption of recombinants resulting in different rearrangements (inverted duplication or terminal deletion) in different offspring (case 23), an interstitial deletion (case 9), and an interstitial duplication (case 18). As suggested by Mules and Stamberg (1984), the rearrangments seen in the latter two cases can be explained by unequal crossing-over due to the difficulty in pairing at the base of the inversion loop. Our case (case 29) is unique in that an interstitial duplication has occurred inside an inversion loop. Such a rearrangement requires not only unequal crossing-over at the base of the inversion loop but also an odd number of crossing-over within the inversion loop. In contrast to the previous cases with a recombinant chromosome, the nearly whole part of the chromosome arm was inverted in our case so that more than one crossing-overs were likely to take place within the inversion loop. The fact that the father was the inversion carrier also indicated a potential risk for a liveborn recombinant even to a male carrier. It should be noted that the two cases (cases 18 and 29) possessed a tiny interstitial duplication, which was difficult to detect by the conventional banding technique alone. This implies that a subtle 'aneusomic recombination' may be a possible cause for the altered phenotype in a case where an apparently same paracentric inversion as in a parent is present. In such cases, diligent chromosome examinations by using high-resolution banding methods are warranted.

It is expected that unstable dicentric or acentric recombinants derived from crossing-over in the meiotic paracentric inversion loop reduce gametic or embryonic viability. Four cases have been ascertained through multiple spontaneous abortions. In this context, the question of whether paracentric inversions are really associated with spontaneous abortions may arise. To test the hypothesis, we investigated the reproductive histories of inversion carriers and the ratio of paracentric inversions in systematic surveys of couples with recurrent spontaneous abortions. In the first place, the combined data in Table 1 showed that 45 inversion carriers were found to have a total of 144 recorded pregnancies, resulting in 30 spontaneous abortions $(20.8 \%), 46$ liveborn individuals with the same inversion as the parents $(32.0 \%), 7$ liveborn individuals with recombinant chromosomes $(4.9 \%), 28$ karyotypically normal individuals $(19.4 \%$ ), and 33 individuals with undetermined karyotypes $(22.9 \%)$. The incidence of spontaneous abortions in inversion carriers is significantly higher than that in the general population $(15 \%$, Poland et al., 1977) $\left(\mathrm{df}=1, \chi^{2}=3.84, \mathrm{p}<0.05\right)$. However, the result is controversial, since the comparison neglected the racial differences in the ratio of spontaneous abortions. Second, if paracentric inversions are related causally to spontaneous abortions as pericentric inversions, the ratio of paracentric inversions to pericentric inversions in repeated aborters would be similar to that in the general population. The ratio from the recently reported systematic surveys of couples with recurrent spontaneous

Vol. 30, No. 2, 1985 
Table 1. Reported cases

\begin{tabular}{|c|c|c|c|}
\hline $\begin{array}{l}\text { Case } \\
\text { No. }\end{array}$ & Reference & Sex & Karyotype \\
\hline 1 & Del Solar and Uchida (1974) & $\mathrm{M}$ & $\operatorname{inv}(16)(q 11 q 22) m a t$ \\
\hline 2 & Shimba et al. (1976) & $\mathrm{M}$ & $\operatorname{inv}(7)(q 22 q 31)$ \\
\hline 3 & Bass et al. (1978) & $\mathrm{F}$ & $\operatorname{inv}(3)(q 13 q 26)$ pat \\
\hline 4 & Canki and Dutrillaux (1979) & M & $\operatorname{inv}(5)(q 21 q 32) m a t$ \\
\hline 5 & Ibid. & $\mathrm{F}$ & $\operatorname{inv}(7)(q 11.3 \mathrm{q} 22.3) \mathrm{pat}$ \\
\hline 6 & De Roover et al. (1979) & $\mathrm{F}$ & inv(1)(p22p36)pat \\
\hline 7 & Fryns and Van den Berghe (1979) & M & $\operatorname{inv}(3)(\mathrm{p} 13 \mathrm{p} 25) \mathrm{mat}$ \\
\hline 8 & Riccardi and Holmquist (1979) & $\mathrm{F}$ & $\operatorname{inv}(13)(\mathrm{q} 12 \mathrm{q} 22)$ \\
\hline 9 & Sparkes et al. (1979) & $\mathrm{F}$ & $\operatorname{rec}(13), \operatorname{del}(q 14 q 22)$, inv(13)(q12q22)mat \\
\hline 10 & Jaeken et al. (1980) & M & $\operatorname{inv}(14)(q 13 q 24)$ \\
\hline 11 & Fryns and Van den Berghe (1980) & $\mathrm{M}$ & $\operatorname{inv}(3)(\mathrm{p} 13 \mathrm{p} 25) \mathrm{mat}$ \\
\hline 12 & lbid. & $\mathrm{M}$ & $\operatorname{inv}(3)(\mathrm{p} 13 \mathrm{p} 25) \mathrm{pat}$ \\
\hline 13 & Ibid. & M & $\operatorname{inv}(5)(q 13 q 34)$ \\
\hline 14 & Ibid. & $\mathrm{F}$ & inv(12)(q12q24)mosaic \\
\hline 15 & Ridler and Sutton (1981) & F & $\operatorname{inv}(7)(q 11 q 22)$ pat \\
\hline 16 & Poulsen et al. (1981) & $\mathrm{M}$ & inv(12)(p12.3p13.1)pat \\
\hline 17 & Singh (1981) & M & $\operatorname{inv}(13)(q 15 q 24)$ mat \\
\hline 18 & Hoo et al. $(1982)$ & $\mathrm{F}$ & $\operatorname{rec}(7), \operatorname{dup}(q 11.22), \operatorname{inv}(7)(\mathrm{q} 11 \mathrm{q} 22) \mathrm{mat}$ \\
\hline 19 & Peters-Slough et al. (1982) & $\mathrm{F}$ & $\operatorname{inv}(3)(\mathrm{p} 13 \mathrm{p} 25) \mathrm{mat}$ \\
\hline 20 & Orye and Van Bever (1983) & $\mathrm{F}$ & inv(7)(q11q22)pat \\
\hline 21 & Ibid. & M & inv(11)(q13q23)mat \\
\hline 22 & Romain et al. (1983) & $\mathrm{M}$ & inv(1)(p31.2p36.22)mat \\
\hline 23 & Valcárcel et al. (1983) & $F$ & $\operatorname{rec}(5)$, del(pterp14), inv(5)(pterp13)mat \\
\hline 24 & Stetten and Rock (1983) & $\mathrm{F}$ & inv(7)(p15p22)mat \\
\hline 25 & Djalali et al. (1984) & $\mathrm{F}$ & $\operatorname{inv}(3)(q 21 q 25.1)$ pat \\
\hline 26 & Venter et al. (1984) & $\mathrm{F}$ & inv(10)(q11q26)mat \\
\hline 27 & Mules and Stamberg (1984) & $\mathrm{M}$ & $\begin{array}{l}\text { rec(14), inv dup(q24.2 } \rightarrow \text { pter }), \text { inv(14) } \\
(\mathrm{q} 24.2 \mathrm{q} 32.3) \mathrm{mat}\end{array}$ \\
\hline 28 & Present case 1 & $\mathrm{~F}$ & $\operatorname{inv}(3)(q 25 q 27)$ \\
\hline 29 & Present case 2 & $\mathrm{~F}$ & $\operatorname{rec}(3), \operatorname{dup}(q 26.3), \operatorname{inv}(3)(q 12 q 29)$ pat \\
\hline
\end{tabular}


with paracentric inversions. ${ }^{2}$

\begin{tabular}{|c|c|c|c|}
\hline Phenotype & $\begin{array}{l}\text { No. of } \\
\text { pregnancy b }\end{array}$ & $\begin{array}{c}\text { No. of } \\
\text { spontaneous } \\
\text { abortion }{ }^{b}\end{array}$ & Comments \\
\hline Hypotonic newborn & 5 & 0 & \\
\hline Normal & 2 & 0 & Systematic chromosome study \\
\hline 10q trisomy syndrome & 6 & 0 & \\
\hline Klinefelter syndrome & 2 & 0 & \\
\hline Turner syndrome & 5 & 3 & \\
\hline $\begin{array}{l}\text { Extreme mental retardation and } \\
\text { multiple congenital anomalies }\end{array}$ & 3 & 0 & \\
\hline Slight psychomotor retardation & 8 & 0 & \\
\hline $\begin{array}{l}\text { Mild mental retardation and multiple } \\
\text { minor anomalies }\end{array}$ & - & - & de novo \\
\hline $13 q-$ syndrome, retinoblastoma & 1 & 0 & \\
\hline $\begin{array}{l}\text { Extreme mental retardation and } \\
\text { multiple congenital anomalies }\end{array}$ & - & - & de novo \\
\hline Slight psychomotor retardation & 1 & 0 & \\
\hline Normal & 1 & 0 & Prenatally detected \\
\hline Normal & 2 & 0 & Father of a 21 trisomy girl \\
\hline Normal & 3 & 2 & Multiple spontaneous abortions \\
\hline Normal & 7 & 3 & Prenatally detected \\
\hline Normal & 3 & 0 & \\
\hline Klinefelter syndrome & - & - & \\
\hline Multiple malformations & 1 & 0 & \\
\hline Growth retardation & 5 & 3 & Three previous miscarriages \\
\hline Normal & 1 & 0 & Acute leukemia \\
\hline Normal & 2 & 0 & Hypoparathroidism \\
\hline Mild mental retardation & 22 & 3 & \\
\hline Cri-du-chat syndrome & 13 & 4 & Two sibs: $5 p$ duplication \\
\hline Normal & 9 & 6 & Multiple spontaneous abortions \\
\hline Normal & 4 & 2 & $\begin{array}{l}\text { Prenatally detected, two previous } \\
\text { miscarriages }\end{array}$ \\
\hline Normal & 30 & 1 & $\begin{array}{l}\text { Prenatal test for advanced } \\
\text { maternal age }\end{array}$ \\
\hline Multiple congenital anomalies & 1 & 0 & \\
\hline Normal & 3 & 3 & Multiple spontaneous abortion \\
\hline $\begin{array}{l}\text { Psychomotor retardation and multiple } \\
\text { minor anomalies }\end{array}$ & 4 & 0 & \\
\hline
\end{tabular}

Vol. 30, No. 2, 1985 
abortions (Turleau et al., 1979; Antich et al., 1980; Ward et al., 1980; Simpson et al., 1981; Husslein et al., 1982; Michels et al., 1982; Osztovics et al., 1982; Diedrich et al., 1983; FitzSimmons et al., 1983; Fryns et al., 1984) is $4: 14$, a figure similar to the ratio of $10: 26$ ascertained in the prenatal diagnosis (Van Dyke et al., 1983; Hook et al., 1984). These arguments lead us to suppose that paracentric inversions are associated with spontaneous abortions at least in some inversion carriers. In fact, the interpretation in our case (case 28) and case 24 is complicated by the presence of the uterine malformation. To confirm the causal relationship between paracentric inversions and spontaneous abortions, further case studies including complete gynecological evaluations are required.

\section{REFERENCES}

Antich, J., Clusellas, N., Twose, A., and Godó, R.M. 1980. Chromosomal abnormalities in parents in cases of reproductive failure. Clin. Genet. 17: 52A.

Bass, H.N., Sparkes, R.S., Crandall, B.F., and Tannenbaum, S.M. 1978. Familial partial trisomy 10q(q23-qter) syndrome and paracentric inversion $3(\mathrm{q} 13 \mathrm{q} 26)$ in the same patient. Ann. Génét. 21: 74-77.

Bühler, E.M. 1983. Unmasking of heterozygosity by inherited balanced translocations. Implications for prenatal diagnosis and gene mapping. Ann. Génét. 26: 133-137.

Canki, N. and Dutrillaux, B. 1979. Two cases of familial inversion in man associated with sex chromosome anomaly. Hum. Genet. 47: 261-268.

Del Solar, C. and Uchida, I.A. 1974. Identification of chromosomai abnormalities by quinacrinestaining technique in patients with normal karyotypes by conventional analysis. J. Pediatr. 84: 534-538.

Deroover, J., Fryns, J.P., Haegeman, J., and Van den Berghe, H. 1979. Paracentric inversion in the short arm of chromosome 1. Hum. Genet. 49: 117-121.

Diedrich, U., Hansman, I., Janke, D., Opitz, O., and Probeck, H.-D. 1983. Chromosome anomalies in 136 couples with a history of recurrent abortions. Hum. Genet. 65: 48-52.

Djalari, M., Steinbach, P., and Barbi, G. 1984. Familial paracentric inversion inv(3)(q21q25.1): Case report and review of the literature. Ann. Génét. 27: 41-44.

FitzSimmons, J., Jackson, D., Wapner, R., and Jackson, L. 1983. Subsequent reproductive outcome in couples with repeated pregnancy loss. Am. J. Med. Genet. 16: 583-587.

Fryns, J.P. and Van den Berghe, H. 1979. Familial paracentric inversion of the short arm of chromosome 3. Ann. Génét. 22: 163-164.

Fryns, J.P. and Van den Berghe, H. 1980. Paracentric inversion in man: Personal experience and review of the literature. Hum. Genet. 54: 413-416.

Fryns, J.P., Kleczkowska, A., Kubien, E., Petit, P., and Van den Berghe, H. 1984. Cytogenetic surveys in couples with recurrent fetal wastage. Hum. Genet. 65: 336-354.

Hoo, J.J., Lorenz, R., Fischer, A., and Fuhrmann, W. 1982. Tiny interstitial duplication of proximal $7 \mathrm{q}$ in association with a maternal paracentric inversion. Hum. Genet. 62: 113-116.

Hook, E.B. and Hammerton J.L. 1977. The frequency of chromosome abnormalities detected in consecutive newborn studies-differences between studies-results by sex and by severity of phenotypic involvement. In Population Cytogenetics, Hook, E.B. and Poter, I.H., ed., Academic Press, New York, pp. 63-79.

Hook, E.B., Schreinemachers, D.M., Willey, A.M., and Cross, P.K. 1984. Inherited structural cytogenetic abnormalities detected incidentally in fetuses diagnosed prenatally: Frequency, parental-age associations, sex-ratio trends, and comparisons with rates of mutants. Am.J. 
Hum. Genet. 36: 422-443.

Husslein, P., Huber, J., Wagenbichler, P., and Schnedl, W. 1982. Chromosome abnormalities in 150 couples with multiple spontaneous abortions. Fertil. Steril. 37: 379-383.

Jacobs, P.A. 1974. Correlations between euploid structural chromosome rearrangements and mental subnormality in humans. Nature 249: 164-165.

Jaeken, J., Fryns, J.P., Standaert, L., De Cock, P., and Van den Berghe, H. 1980. De novo paracentric inversion in a microcephalic boy: 46,XY,inv(14)(q13q24). Ann. Génét. 23: 105-107.

Michels, V.V., Medrano, C., Venne, V.L., and Riccardi, V.M. 1982. Chromosome translocations in couples with multiple spontaneous abortions. Am. J. Hum. Genet. 34: 507-513.

Mules, E.H. and Stamberg, J. 1984. Reproductive outcomes of paracentric inversion carriers: Report of a liveborn dicentric recombinant and literature review. Hum. Genet. 67: 126-131.

Orye, E. and Van Bever, H. 1983. Paracentric inversions: Two new familial cases, inv(7)(q22q11) and inv(11)(q23q13). J. Med. Genet. 20: 231-232.

Osztovics, M.K., Tóth, S.P., and Wessely, J.A. 1982. Cytogenetic investigations in 418 couples with recurrent fetal wastage. Ann. Génét. 25: 232-236.

Peters-Slough, M.F., Planteydt, H.T., Timmerman, M.J., and v.D. Vooren, M.J. 1982. A familial paracentric inversion in the short arm of chromosome 3: A case report. Clin. Genet. 22: 102104.

Poland, B.J., Miller, J.R., Jones, D.C., and Trimble, B.K. 1977. Reproductive counceling in patients who have had a spontaneous abortion. Am. J. Obstet. Gynecol. 127: 685-691.

Poulsen, H., Mikkelsen, M., and Holmgren, G. 1981. Peri- and paracentric inversions in chromosome 12: Prenatal diagnosis and family study. Prenatal Diag. 1: 35-42.

Riccardi, V.M. and Holmquist, G.P. 1979. De novo 13q paracentric inversion in a boy with cleft palate and mental retardation. Hum. Genet. 52: 211-215.

Ridler, M.A.C. and Sutton, S.D. 1981. A case of paracentric inversion inv(7)(q11q22): Prenatal detection and counselling. Prenatal Diag. 1: 81-84.

Romain, D.R., Columbano-Green, L.M., Whyte, S., Smythe, R.H., Parfitt, R.G., Gebbie, O.B., and Chapman, C.J. 1983. Familial paracentric inversion of 1p. Am. J. Med. Genet. 14: 629634.

Shimba, H., Ohtaki, K., Tanabe, K., and Sofuni, T. 1976. Paracentric inversion of a human chromosome 7. Hum. Genet. 31: $1-7$.

Simpson, J.L., Elias, S., and Martin, A.O. 1981. Parental chromosomal rearrangements associated with repetitive spontaneous abortions. Fertil. Steril. 36: 584-589.

Singh, R.P. 1981. Klinefelter's syndrome with a 47,XXY,inv(12)(q15q24) karyotype. Clin. Genet. 19: $188-190$.

Sparkes, R.S., Muller, H., and Klisak, I. 1979. Retinoblastoma with 13q - chromosomal deletion associated with maternal paracentric inversion of 13q. Science 203: 1027-1029.

Stetten, G. and Rock, J.A. 1983. A paracentric chromosomal inversion associated with repeated early pregnancy wastage. Fertil. Steril. 40: 124-126.

Turleau, C., Chavin-Colin, F., and de Grouchy, J. 1979. Cytogenetic investigation in 413 couples with spontaneous abortions. Eur. J. Obstet. Gynec. Reprod. Biol. 9: 65-74.

Varcárcel, E., Benítez, J., Martínez, P., Rey, J.A., and Sánchez Cascos, A. 1983. Cytogenetic recombinants from a female carrying a paracentric inversion of the short arm of chromosome number 5. Hum. Genet. 63: 78-81.

Van Dyke, D.L., Weiss, L., Roberson, J.R., and Ramesh Babu, V. 1983. The frequency and mutation rate of balanced autosomal rearrangements in man estimated from prenatal genetic studies for advanced maternal age. Am. J. Hum. Genet. 35: 301-308.

Venter, P.A., Dawson, B., Du Toit, J.L., Smith, E.L., Kritzinger, N., Landman, A.S., Cronje, A.S., and Op't Hof, J. 1984. A familial paracentric inversion: A short review of the current status. Hum. Genet. 67: 121-125.

Ward, B.E., Henry, G.P., and Robinson, A. 1980. Cytogenetic studies in 100 couples with recurrent spontaneous abortions. Am. J. Hum. Genet. 32: 549-553.

Yu, C.W., Borgaonkar, D.S., and Bolling, D.R. 1976. Paracentric inversion in man. Hum. Genet. 34: 117 . 